(Received 12 July, 1999 ; Accepted 9 September, 1999)

\title{
Sorption of Metal Ions by Bead Cellulose Grafted with Amidoximated Polyacrylonitrile
}

\author{
Nobuyoshi Aoki ${ }^{* 1}$, Kounosuke Tanaka ${ }^{* 2}$, Munenori Sakamoto ${ }^{* 3}$, and Ken-ichi Furuhata*2 \\ ${ }^{* 1}$ Molecular Engineering Division, Kanagawa Industrial Technology Research Institute, 705-1, \\ Shimoimaizumi, Ebina-shi, 243-0435, Japan \\ ${ }^{* 2}$ Department of Organic and Polymeric Materials, Graduate School of Science and Engineering, Tokyo \\ Institute of Technology, 2-12-1, O-okayama, Meguro-ku, Tokyo, 152-8552, Japan \\ ${ }^{* 3}$ College of Education, Joetsu University of Education, Yamayashiki-machi, Joetsu-shi, 943-8512, Japan
}

\begin{abstract}
Bead cellulose samples with amidoximated polyacrylonitrile grafts were examined as sorbents for metal ions. The amount of the ion sorbed from $40 \mathrm{mM}$ solution in a fixed period increased in the order $\mathrm{Cd}$ (II), $\mathrm{Zn}$ (II) $<\mathrm{Pb}$ (II) $<\mathrm{Cu}$ (II) $\ll \mathrm{Ag}$ (I). The treatment of bead samples with $\mathrm{NaOH}$ solutions caused the swelling, and both the amount of the metal ion sorbed and the sorption rate increased considerably after the $\mathrm{NaOH}$ treatment. More than $90 \%$ of metal ions sorbed by the beads were desorbed in $0.5 \mathrm{M} \mathrm{H}_{2} \mathrm{SO}_{4}$. The sorption-desorption- $\mathrm{NaOH}$ treatment cycle could be repeated without significant reduction in the extent of sorption.
\end{abstract}

\section{Introduction}

The sorption of metal ions from aqueous solutions is important, for example, for the recovery of precious metals from seawater and the exclusion of toxic metals from waste waters, and various chelating resins have been examined for the purpose. Examples are polymers having amidoxime groups which were tested most frequently for the recovery of uranium from seawater [1,2]. Amidoxime compounds form colored complexes with some kinds of metal ions and several of them are used in the quantitative analysis of metals [3].

Amidoxime resins are obtained via the amidoximation of nitrile groups in polymers (for example, polyacrylonitrile) with hydroxylamine. Graft copolymers of acrylonitrile with starch [4] and cellulose [5] were used as sorbents for metal ions after amidoximation. The polysaccharide matrix is considered to have some advantages because it is hydrophilic and biodegradable in nature. The shape of sorbent is important for the sorption performance and fibrous [6-9] and porous $[10,11]$ samples having high relative surface area were tested.

We reported previously [12] the graft copolymerization of acrylonitrile onto microporous bead cellulose and the amidoximation of polyacrylonitrile grafts. About $40 \%$ of the nitrile groups could be converted into amidoxime groups. In this article we describe the sorption of several metal ions by these amidoximated bead cellulose samples. The effect of $\mathrm{NaOH}$ treatment on the sorption behavior was studied. These bead samples showed no significant decrease in the performance after repeated sorption-desorption- $\mathrm{NaOH}$ treatment cycles.

\section{Experimental}

\subsection{Materials}

Samples of bead cellulose (Bellfine; diameter $70-100$ $\mu \mathrm{m}$; water content $74 \%$ ) were kindly supplied by Kanebo Co., Ltd. Acrylonitrile was grafted onto bead cellulose at $40^{\circ} \mathrm{C}$ for $4 \mathrm{~h}$ using $\left(\mathrm{NH}_{4}\right)_{2} \mathrm{Ce}\left(\mathrm{NO}_{3}\right)_{6}$ as an initiator and graft copolymers were treated with 
hydroxylamine in methanol at $90^{\circ} \mathrm{C}$ in a pressure bottle as described in the previous paper [12]. Amidoximated bead cellulose (Cell-g-PAAmd) samples were washed with water repeatedly, then with acetone and were immersed in acetone for $30 \mathrm{~min}$. The beads were then filtered, left in open air for $30 \mathrm{~min}$ and were dried under diminished pressure at room temperature. Some of amidoximated samples were treated with $\mathrm{NaOH}$ solutions at $40^{\circ} \mathrm{C}$ (for example, for $24 \mathrm{~h}$ in $0.5 \mathrm{M} \mathrm{NaOH}$ ), washed with distilled water until the washings became neutral and were dried under diminished pressure at room temperature prior to the sorption experiment.

Reagent grade products of $\mathrm{AgNO}_{3}, \mathrm{CdSO}_{4} \cdot 8 / 3 \mathrm{H}_{2} \mathrm{O}$, $\mathrm{CoCl}_{2} \cdot 6 \mathrm{H}_{2} \mathrm{O}, \mathrm{CuSO}_{4} \cdot 5 \mathrm{H}_{2} \mathrm{O}, \mathrm{NiCl}_{2}, \mathrm{~Pb}\left(\mathrm{NO}_{3}\right)_{2}$, and $\mathrm{Zn}\left(\mathrm{NO}_{3}\right)_{2} \cdot 6 \mathrm{H}_{2} \mathrm{O}$ were used without further purification. In order to determine the uranium content, a sample of purchased $\mathrm{UO}_{2}\left(\mathrm{NO}_{3}\right)_{2}$ was converted to $\mathrm{U}_{3} \mathrm{O}_{8}$ by heating for $2 \mathrm{~h}$ at $900^{\circ} \mathrm{C}$ and weighed.

\subsection{Sorption}

The sorption experiments for $\mathrm{Cu}$ (II) were studied in an acetate buffer ( $\mathrm{pH}$ 5.1) while aqueous solutions were used for other ions. The $\mathrm{pH}$ values for $\mathrm{Ag}$ (I), $\mathrm{Cd}$ (II), $\mathrm{Co}$ (II), $\mathrm{Cu}$ (II), $\mathrm{Ni}$ (II), $\mathrm{Pb}$ (II) and $\mathrm{Zn}$ (II) solutions were 5.4, 5.3, 5.6, 4.3, 7.4, 4.4 and 5.4, respectively. A Cell-g. PAAmd sample (dry weight, $140 \mathrm{mg}$ ) and a metal salt solution $(40 \mathrm{mM}, 50 \mathrm{~mL})$ were added to a flask and the content was shaken for a prescribed period $(1-701 \mathrm{~h})$ at $40^{\circ} \mathrm{C}$. The amount of the metal sorbed by the sample was calculated from the decrease in the metal ion concentration of the solution. In the sorption experiments for $\mathrm{UO}_{2}$ (II), $20 \mathrm{mg}$ of Cell-g.PAAmd sample and $100 \mathrm{~mL}$ of $0.42 \mathrm{mM} \mathrm{UO}_{2}\left(\mathrm{NO}_{3}\right)_{2}$ solution were used (experiments using uranium compounds in higher concentrations is not recommended in Japan).

The desorption of $\mathrm{Cu}$ (II) from Cell-g-PAAmd beads was studied in $\mathrm{HCl}$ and $\mathrm{H}_{2} \mathrm{SO}_{4}$ solutions. In a typical experiment, $430 \mathrm{mg}$ of Cell-g.PAAmd sample which sorbed $56 \mathrm{mg}$ of $\mathrm{Cu}$ (II) was added to a flask containing $100 \mathrm{~mL}$ of $0.7 \mathrm{M} \mathrm{HCl}$ and the mixture was kept at $15^{\circ} \mathrm{C}$ with shaking. The concentration of $\mathrm{Cu}$ (II) in the solution was measured at prescribed time intervals and the amount of $\mathrm{Cu}$ (II) desorbed was calculated.

\subsection{Recycling}

In a recycling experiment, the sorption-desorption cycle was repeated four times. A Cell $-g$-PAAmd sample treated with $0.5 \mathrm{M} \mathrm{NaOH}$ for $24 \mathrm{~h}$ at $40^{\circ} \mathrm{C}(510 \mathrm{mg})$ was immersed in $40 \mathrm{mM} \mathrm{CuSO}_{4}$ solution $(50 \mathrm{~mL})$, incubated for $24 \mathrm{~h}$ at $40^{\circ} \mathrm{C}$ and the amount of $\mathrm{Cu}$ (II) sorbed was determined (sorption). The beads were filtered off, washed with distilled water and dried with the procedure described in 2.1. Only a negligible amount of $\mathrm{Cu}$ (II), if any, was desorbed in the washing step. The washed beads were then soaked in $0.5 \mathrm{M} \mathrm{H}_{2} \mathrm{SO}_{4}(50 \mathrm{~mL})$ for $1 \mathrm{~h}$ at $40^{\circ} \mathrm{C}$ and the amount of $\mathrm{Cu}$ (II) desorbed was determined (desorption). The beads were filtered off, washed with distilled water and dried with the aforementioned procedure. The dried beads were treated again with $0.5 \mathrm{M} \mathrm{NaOH}$ for $24 \mathrm{~h}$ at $40^{\circ} \mathrm{C}$, washed and dried as before, and were used in the next cycle.

\subsection{Analyses}

Table 1 summarizes the quantitation methods for the metal ions. In the treatment of a sample solution containing uranium $(0.5-10 \mathrm{mg})$ for analysis, $10 \mathrm{~mL}$ of $10 \% \mathrm{Na}_{2} \mathrm{CO}_{3}$ and $3 \mathrm{~mL}$ of $10 \% \mathrm{NaOH}$ were added to the solution and the volume of the solution was increased to $50 \mathrm{~mL}$ with water. The solution was then boiled until the volume was reduced to about $25 \mathrm{~mL}$. After cooling, $5 \mathrm{~mL}$ of $10 \% \mathrm{NaOH}$ and $3 \mathrm{~mL}$ of $3 \% \mathrm{H}_{2} \mathrm{O}_{2}$ were added to the solution and the final volume was adjusted to 50 $\mathrm{mL}$ with distilled water for colorimetry.

The anion exchange capacity (AEC) and cation exchange capacity (CEC) of a Cell-g-PAAmd sample were determined from the amounts of $\mathrm{HCl}$ and $\mathrm{NaOH}$ consumed by the sample. A Cell-g-PAAmd sample (250 $\mathrm{mg}$ ) was incubated in $0.1 \mathrm{M} \mathrm{HCl}(50 \mathrm{~mL})$ for $24 \mathrm{~h}$ at $40^{\circ} \mathrm{C}$. An aliquot $(5 \mathrm{~mL})$ was pipetted from the supernatant and titrated with $0.1 \mathrm{M} \mathrm{NaOH}$. The apparent $A E C$ value of the sample was calculated from

Table 1 Quantitation of Metal Ions

\begin{tabular}{|c|c|c|c|}
\hline Ion & Salt & Quantitation & $\begin{array}{l}\text { Indicator or } \\
\text { Color Former }\end{array}$ \\
\hline $\operatorname{Ag}(1)$ & $\mathrm{AgNO}_{3}$ & Titration with $\mathrm{NH}_{4} \mathrm{SCN}(0.05 \mathrm{M})$ & $\left(\mathrm{NH}_{4}\right) \mathrm{Fe}\left(\mathrm{SO}_{4}\right)_{2}$ \\
\hline Cd(II) & $\mathrm{CdSO}_{4}$ & Titration with EDTA $(0.01 \mathrm{M})$ & $\mathrm{X} 0^{2 \nmid}$ \\
\hline $\operatorname{Co}(I I)$ & $\mathrm{CoCl}_{2}$ & Colorimetry $(625 \mathrm{~nm})$ & $\mathrm{NH}_{4} \mathrm{SCN}$ \\
\hline $\mathrm{Cu}(\mathrm{II})$ & $\mathrm{CuSO}_{4}$ & Titration with EDTA $(0.01 \mathrm{M})^{\mathrm{b}}$ & PAN $^{c \prime}$ \\
\hline $\mathrm{Ni}(\mathrm{II})$ & $\mathrm{NiCl}_{2}$ & Colorimetry $(465 \mathrm{~nm})$ & dimethylglyoxime \\
\hline $\mathrm{Pb}(\mathrm{II})$ & $\mathrm{Pb}\left(\mathrm{NO}_{3}\right)_{2}$ & Titration with EDTA $(0.01 \mathrm{M})$ & $X 0^{a)}$ \\
\hline $\mathrm{UO}_{2}$ (II) & $\mathrm{UO}_{2}\left(\mathrm{NO}_{3}\right)_{2}$ & Colorimetry $(580 \mathrm{~nm})$ & $\mathrm{H}_{2} \mathrm{O}_{2}$ \\
\hline $\ln (I)$ & $\mathrm{Zn}\left(\mathrm{NO}_{3}\right)_{2}$ & Titration with EDTA $(0.01 \mathrm{M})$ & $X 0^{a)}$ \\
\hline
\end{tabular}

${ }^{\mathrm{a}}$ Xylenol Orange. ${ }^{\mathrm{D}}$ In buffer at $\mathrm{pH}$ 5.1.

c) 1-(2-Pyridylazo) -2-naphthol. 
the amount of $\mathrm{HCl}$ consumed. The beads were then washed with distilled water until the washings became neutral to Methyl Orange, then with acetone and dried under diminished pressure at room temperature. The dried sample $(170 \mathrm{mg})$ was kept in $0.1 \mathrm{M} \mathrm{NaOH}(50 \mathrm{~mL})$ for $24 \mathrm{~h}$ at room temperature with shaking. An aliquot from the supernatant $(5 \mathrm{~mL})$ was used for the determination of the amount of $\mathrm{NaOH}$ consumed (A). Another aliquot $(5 \mathrm{~mL})$ was used for the determination of the amount of the chloride ion liberated (B). The apparent $C E C$ value was calculated from the difference, $A-B$.

\section{Results and Discussion}

\subsection{Contents of Ionizable Groups}

The amidoxime compounds are amphoteric and hence soluble in both acidic and alkaline solutions [3], and amidoxime groups coordinate to many kinds of metal ions. The amidoxime content of the bead cellulose having amidoximated polyacrylonitrile or polyacrylamidoxime grafts (Cell-g-PAAmd) was calculated from the nitrogen content of bead cellulose grafted with polyacrylonitrile (Cell-g.PAN) and that of Cell.g-PAAmd derived from it assuming that no side reaction had occurred [12]. In the Cell-g-PAAmd samples, however, functional groups other than amidoxime are considered to be present in addition to intact nitrile group, such as hydroxamic acid, carboxylic acid [13] and imidedioxime [14] groups. Most of these groups were also effective in the sorption of heavy metal ions [14-17] when introduced into resins.

The contents of ionizable groups were estimated with the apparent value of anion exchange capacity (AEC, or the amount of proton accepting groups) and with that of cation exchange capacity (CEC, or the amount of proton releasing groups) [18]. Fig. la shows AEC, CEC and the amount of $\mathrm{Pb}(\mathrm{II})$ sorbed (for $211 \mathrm{~h}$ at $40^{\circ} \mathrm{C}$ ) as a function of the calculated amidoxime content. The three values increased with increasing amidoxime content with some extent of fluctuation. Fig. lb shows that the amount of $\mathrm{Pb}$ (II) sorbed increased steadily with increasing AEC. The CEC showed a similar tendency but the linearity was much inferior. These findings show that the assumption adopted in the calculation of amidoxime content did not always hold and some side reactions must have occurred during amidoximation to
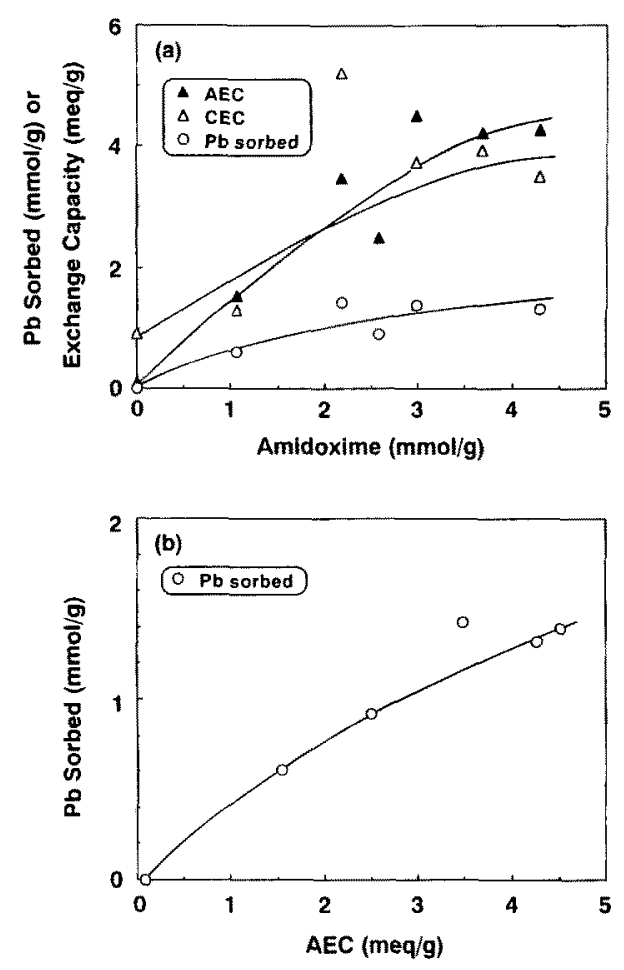

Fig. 1 Relation among AEC, CEC, amount of $\mathrm{Pb}$ (II) sorbed and amidoxime content. Sorption conditions; for $211 \mathrm{~h}$ at $40^{\circ} \mathrm{C}$ in 40 $\mathrm{mM} \mathrm{Pb}\left(\mathrm{NO}_{3}\right)_{2}$ solution.

an extent different from sample to sample. For most Cell-g.PAAmd samples, the AEC value was higher than the $C E C$ value and the difference became larger if the amount of $\mathrm{NaOH}$ consumed by the stem cellulose 0.907 $\mathrm{mmol} / \mathrm{g}$ dry sample) was subtracted from the CEC value. This suggests that the conversion of amidoxime groups to hydroxamic acid and/or carboxylic acid groups did not occur to a large extent. Another possible reason is that the amidoxime group of Cell- $g$.PAAmd is relatively a base rather than an acid [19]. A Cell-g. PAAmd sample having next analytical values (Sample No. 1) was used in the following experiments unless otherwise noted: amidoxime content, $2.99 \mathrm{mmol} / \mathrm{g}$ dry beads; AEC, $4.51 \mathrm{meq} / \mathrm{g}$ dry beads; CEC, $3.74 \mathrm{meq} / \mathrm{g}$ dry beads.

\subsection{Sorption Behavior}

Table 2 summarizes results of the sorption of eight kinds of metal ions for $1 \mathrm{~h}$ at $40^{\circ} \mathrm{C}$. Original Cell-gPAAmd beads were yellow and the color clearly 
changed to deep green and red after the sorption of $\mathrm{Cu}$ (II) and $\mathrm{UO}_{2}(\mathrm{II})$, respectively.

Fig. 2a shows the time courses of sorption of $\mathrm{Ag}$ (I), $\mathrm{Cd}$ (II), $\mathrm{Cu}(\mathrm{II}), \mathrm{Pb}$ (II), $\mathrm{UO}_{2}$ (II) and $\mathrm{Zn}$ (II) at $40^{\circ} \mathrm{C}$ by Cell.g.PAAmd beads without the $\mathrm{NaOH}$ treatment. The amount of ion sorbed from $40 \mathrm{mM}$ solution in a fixed period and hence the sorption rate increased in the order $\mathrm{Ni}$ (II) $<\mathrm{Cd}$ (II), $\mathrm{Co}$ (II), $\mathrm{Zn}$ (II) $<\mathrm{Pb}$ (II) $<$ $\mathrm{Cu}(\mathrm{II}) \ll \mathrm{Ag}(\mathrm{I})$. This order was the same as that observed for cellulose derivatives enriched in carboxyl groups [17], For $\mathrm{Pb}$ (II), $\mathrm{Cu}$ (II) and $\mathrm{Ag}$ (I), the amounts sorbed at the longest sorption time examined were large but the ratios to AEC values were below 0.5. The value for $\mathrm{Cu}$ (II) was comparable to that reported for an amidoximated cellulose sample [5].

Table 2 Sorption of Metal Ions by Cell-g-PAAmd ${ }^{\text {a }}$

\begin{tabular}{|c|c|c|c|c|}
\hline \multirow[t]{2}{*}{ Ion } & \multicolumn{2}{|c|}{$\begin{array}{l}\text { Without } \mathrm{NaOH} \\
\text { treatment }\end{array}$} & \multicolumn{2}{|c|}{$\begin{array}{c}\text { After } \mathrm{NaOH} \\
\text { treatment }\end{array}$} \\
\hline & $\mathrm{mg} / \mathrm{g}^{\mathrm{b})}$ & $\mathrm{mol} / \mathrm{mol}^{\mathrm{c})}$ & $\mathrm{mg} / \mathrm{g}^{\mathrm{b})}$ & $\mathrm{mol} / \mathrm{molc})$ \\
\hline $\left.\operatorname{Ag}(1)^{d}\right)$ & 104.4 & 0.32 & 288.0 & 0.89 \\
\hline $\mathrm{Cd}(\mathrm{II})$ & 2.0 & 0.006 & & \\
\hline $\mathrm{Co}(\mathrm{II})$ & 11.3 & 0.04 & & \\
\hline $\mathrm{Cu}(\mathrm{II})^{\mathrm{e})}$ & 32.4 & 0.11 & 121.3 & 0.40 \\
\hline $\mathrm{Ni}(\mathrm{II})^{\mathrm{e})}$ & 0.0 & 0.0 & 21.1 & 0.07 \\
\hline $\mathrm{Pb}(\mathrm{II})^{d\rangle}$ & 53.0 & 0.09 & 403.0 & 0.65 \\
\hline $\mathrm{UO}_{2}(\mathrm{II})^{\mathrm{d})}$ & 68.5 & 0.10 & 149.2 & 0.21 \\
\hline $\mathrm{Zn}(\mathrm{II})$ & 8.1 & 0.04 & & \\
\hline
\end{tabular}

asorption; for $1 \mathrm{~h}$ at $40^{\circ} \mathrm{C}$. The initial concentrations of metal ions were $40 \mathrm{mM}$ except for $\mathrm{VO}_{2}(\mathrm{II})(0.42 \mathrm{mM})$. Cell-g-PAAmd sample No. 1 was used for $\mathrm{Ag}$ (I), $\mathrm{Cd}$ (II), $\mathrm{Pb}$ (II), $\mathrm{VO}_{2}$ (II) and $\mathrm{Zn}$ (II). The amidoxime content of the sample used for $\mathrm{Co}(\mathrm{II}), \mathrm{Cu}$ (II) and $\mathrm{Ni}$ (II) was $4.82 \mathrm{mmol} / \mathrm{g}$ dry beads. Its AEC and CEC values were not measured ${ }^{\mathrm{D}}{ }^{\mathrm{m}} \mathrm{meta} \mathrm{mg} / \mathrm{g}$ dry beads. ${ }^{\mathrm{c}}$ metal mol/mol amidoxime group. ${ }^{d} \mathrm{NaOH}$ treatment; for 24 h at $40^{\circ} \mathrm{C}$ in $0.5 \mathrm{M} \mathrm{NaOH} .{ }^{e 3} \mathrm{NaOH}$ treatment; for $38 \mathrm{~h}$ at $40^{\circ} \mathrm{C}$ in $0.1 \mathrm{M} \mathrm{NaOH}$.

At the initial stages, the mole number of $\mathrm{Ag}(\mathrm{I})$ sorbed per weight of beads was more than three times larger than that for $\mathrm{UO}_{2}$ (II) in a fixed sorption period (Table 2). However, the initial concentration of $\mathrm{UO}_{2}(\mathrm{II})$ was $0.42 \mathrm{mM}$ which was about $1 \%$ of those of $\mathrm{Ag}$ (I) and other metal ions $(40 \mathrm{mM})$. In a separate experiment, the amount of $\mathrm{Ag}(\mathrm{I})$ sorbed in $4 \mathrm{~h}$ increased almost linearly with increasing $\mathrm{Ag}(\mathrm{I})$ concentration up to 40 $\mathrm{mM}$. This suggests that, at the same solution

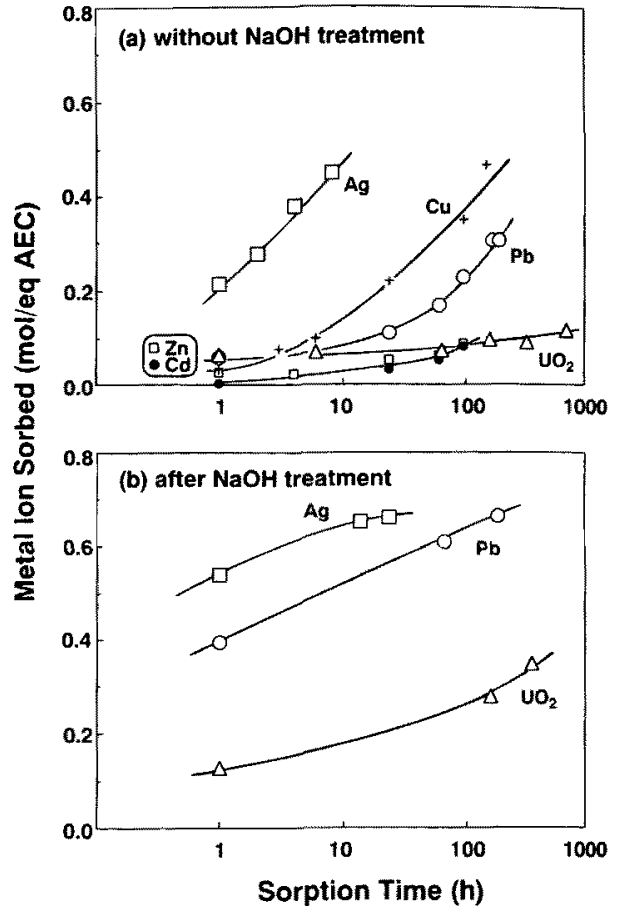

Fig. 2 Time course of sorption at $40^{\circ} \mathrm{C}$ : (a) by Cell. $g$. PAAmd No. 1 without $\mathrm{NaOH}$ treatment; (b) beads were soaked in $0.1 \mathrm{M} \mathrm{NaOH}$ for $24 \mathrm{~h}$ at $40^{\circ} \mathrm{C}$ before the sorption experiments. Ion concentration; $0.42 \mathrm{mM}^{\text {for }} \mathrm{UO}_{2}$ (II) and $40 \mathrm{mM}$ for others.

concentration, the sorption rate for $\mathrm{UO}_{2}$ (II) at initial stages would be about thirty times higher than that for $\mathrm{Ag}(\mathrm{I})$

\section{$3.3 \mathrm{NaOH}$ Treatment}

The alkali treatment of amidoxime resins accelerated the sorption of metal ions $[20,21]$. The treatment with $\mathrm{NaOH}$ solutions caused the swelling of Cell-g.PAAmd beads and the diameters became about three times larger than those before the treatment. After the sorption of $\mathrm{Cu}$ (II), the beads contracted to a size close to that before the $\mathrm{NaOH}$ treatment. Bead cellulose and Cell- $g$-PAN samples did not swell after the treatment in $0.1 \mathrm{M} \mathrm{NaOH}$ for $24 \mathrm{~h}$ at $40^{\circ} \mathrm{C}$.

Fig. $2 \mathrm{~b}$ shows the time dependence of sorption by $\mathrm{NaOH}$-treated beads for $\mathrm{Ag}$ (I), $\mathrm{Pb}$ (II) and $\mathrm{UO}_{2}$ (II). Table 2 shows that the $\mathrm{NaOH}$ treatment increased remarkably the amount of metal ion sorbed and hence the sorption rate for $\mathrm{Ag}$ (I), $\mathrm{Cu}$ (II), $\mathrm{Ni}$ (II), $\mathrm{Pb}$ (II) and 
$\mathrm{UO}_{2}$ (II). More than $60 \%$ of the total sorption was achieved within $1 \mathrm{~h}$. AEC and CEC values increased but only slightly after the $\mathrm{NaOH}$ treatment (for example, from 4.51 to $4.96 \mathrm{meq} / \mathrm{g}$ for $\mathrm{AEC}$ and from 3.74 to 3.76 $\mathrm{meq} / \mathrm{g}$ for $\mathrm{CEC}$ ). The increase in the sorption rate can be ascribed to the swelling while that in the amount of metal ion sorbed may be explained in terms of the increase in the amount of functional groups accessible to metal ions.

The treatment of Cell $\mathrm{g}$.PAAmd beads in $0.7 \mathrm{M} \mathrm{HCl}$ for $1 \mathrm{~h}$ at $40^{\circ} \mathrm{C}$ also accelerated the sorption of $\mathrm{Cu}$ (II) but it was less effective as compared with the $\mathrm{NaOH}$ treatment. The amounts of $\mathrm{Cu}$ (II) sorbed were larger by $40 \%$ and $4 \%$ at the sorption periods of 2 and $9 \mathrm{~h}$, respectively, as compared with the case for untreated beads. After another acid treatment, in $0.5 \mathrm{M} \mathrm{H}_{2} \mathrm{SO}_{4}$ for $1 \mathrm{~h}$ at $40^{\circ} \mathrm{C}$, Cell-g-PAAmd beads swelled only slightly (less than $10 \%$ in diameter). These findings show that the presence of negatively charged groups in Cell-g. PAAmd beads caused the swelling and the increase in the amount of metal ion sorbed. Each anionic group, such as amidoximato or carboxylato group, is considered to affect the sorption behavior of $\mathrm{NaOH}$-treated samples in a different way. The amidoxime group was effective for the recovery of uranium from seawater while the carboxyl group was not [22]. It may be inferred that the amidoxime group was primarily effective for the sorption of metal ions and the carboxyl group was important for the swelling.

\subsection{Recycling}

For the recycling of sorbents which is important from practical view points, it is necessary to desorb effectively the metal ions sorbed. Fig. 3 shows the desorption of $\mathrm{Cu}$ (II) in $0.7 \mathrm{M} \mathrm{HCl}$ at $15^{\circ} \mathrm{C}$. More than $80 \%$ of $\mathrm{Cu}$ (II) sorbed was desorbed in $15 \mathrm{~min}$ and the desorption leveled off at about $90 \%$ in $1 \mathrm{~h}$. Almost all the $\mathrm{Cu}(\mathrm{II})$ sorbed will be desorbed under strongly acidic conditions but the decomposition of amidoxime and other moieties would occur simultaneously as in the case of other amidoxime resins [23]. Therefore, the desorption under highly acidic conditions was not studied.

Fig. 4 shows the change in the infrared spectrum for Cell.g-PAAmd beads during recycling. $A$ band assignable to the amidoxime group was observed around $1660 \mathrm{~cm}^{-1}$. An additional band appeared at

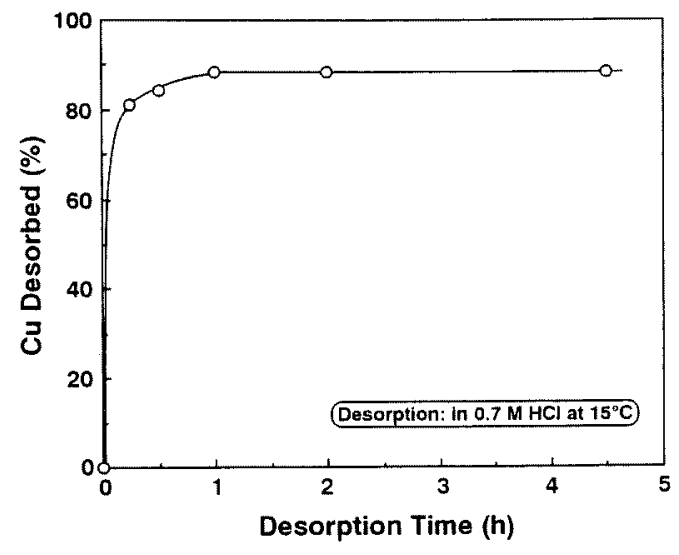

Fig. 3 Desorption of $\mathrm{Cu}$ (II) : $430 \mathrm{mg}$ of $\mathrm{NaOH}$-treated Cell $\mathrm{g}$-PAAmd beads containing $56 \mathrm{mg}$ of $\mathrm{Cu}$ (II) sorbed. $\mathrm{NaOH}$ treatment; for $62 \mathrm{~h}$ at 40 ${ }^{\circ} \mathrm{C}$ in $0.1 \mathrm{M} \mathrm{NaOH}$.

about $1560 \mathrm{~cm}^{-1}$ after the $\mathrm{NaOH}$ treatment ascribable to carboxylate groups (Figs. $4 \mathrm{~b}$ and $4 \mathrm{~d}$ ) and it shifted to $1700 \mathrm{~cm}^{-1}$ after the $\mathrm{H}_{2} \mathrm{SO}_{4}$ treatment (Figs. $4 \mathrm{c}$ and $4 \mathrm{e}$, free carboxyl groups). The absorption at $1104 \mathrm{~cm}^{-1}$ observed in the latter figures was due to sulfate ion. The relative intensity of carboxyl bands seemed to increase slightly while that of amidoxime band decrease due to the repetition of recycling. These findings shows that carboxyl groups were present in an appreciable amount in addition to amidoxime groups in $\mathrm{NaOH}$-treated Cell$g$.PAAmd beads.

Four cycles of sorption-desorption experiments

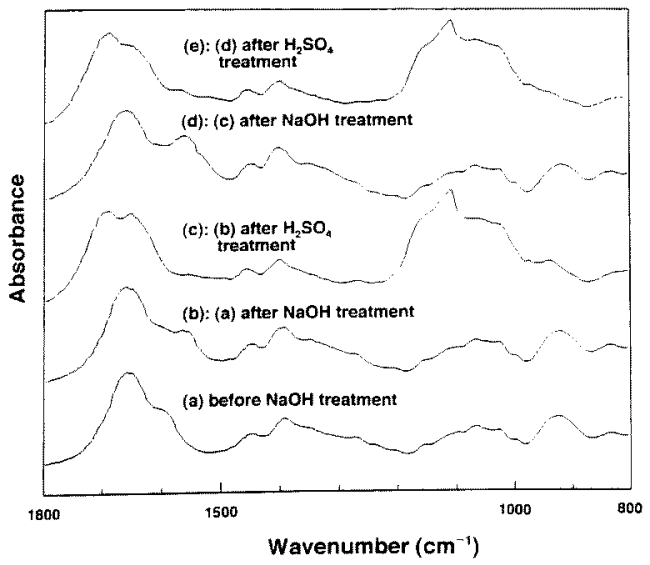

Fig. 4 Change in infrared spectrum of Cell- $g$-PAAmd beads during recycling. 
were carried out to examine the adaptability of Cell $-g$. PAAmd beads for recycling and results are shown in Fig. 5. In the case of samples without the $\mathrm{NaOH}$ treatment, the amount of $\mathrm{Cu}$ (II) sorbed at $40^{\circ} \mathrm{C}$ in $24 \mathrm{~h}$ decreased considerably with the repetition number. For these untreated samples, the sorption time of $24 \mathrm{~h}$ was much shorter than that necessary to reach the sorption equilibrium, and the decrease in the amount of $\mathrm{Cu}$ (II) sorbed can be ascribed to the decrease in the rate of sorption. One of the possible explanations is that $\mathrm{Cu}$ (II) ions remaining in the beads after the desorption might form crosslinking points to decrease the water content of the beads. As described in the above section, the sorption of $\mathrm{Cu}(\mathrm{II})$ caused the deswelling of $\mathrm{NaOH}$-treated beads. For the sample which was treated with $0.5 \mathrm{M} \mathrm{NaOH}$ solution for $24 \mathrm{~h}$ at $40^{\circ} \mathrm{C}$ after each desorption process, the amount of $\mathrm{Cu}$ (II) sorbed also tended to decrease but the decrease was relatively small as compared with that for the beads without the $\mathrm{NaOH}$ treatment.

Cell-g-PAAmd beads studied here sorb several kinds of metal ions. However, their sorption performance seems not to be satisfactory for practical purposes although they have high relative surface area and sufficient mechanical strength. If appropriate improvement will be achieved in increasing amidoxime content and the degree of swelling, Cell- $g$-PAAmd beads will be useful for sorption of several kinds of

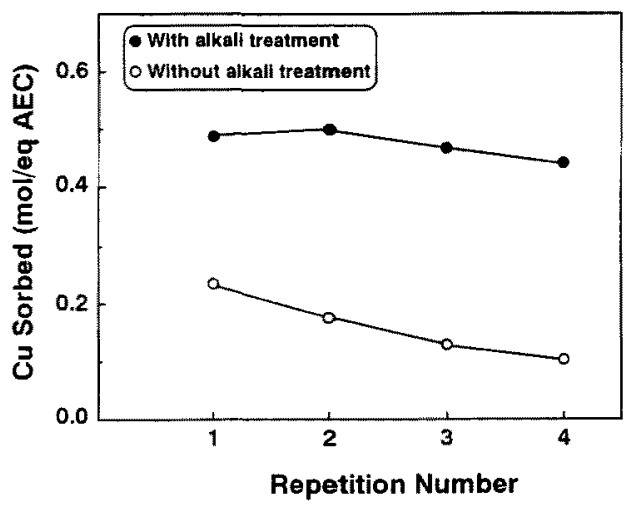

Fig. 5 Repeated use of Cell- $g$.PAAmd beads. Sorption; for $24 \mathrm{~h}$ at $40^{\circ} \mathrm{C}$ in $40 \mathrm{mM} \mathrm{CuSO}_{4}$ solution: Desorption; for $1 \mathrm{~h}$ at $40^{\circ} \mathrm{C}$ in $0.5 \mathrm{M}$ $\mathrm{H}_{2} \mathrm{SO}_{4}$. Cell-g-PAAmd; No. 1. metal ions from aqueous solutions such as the recovery of uranium from seawater in which the uranium concentration is about $10^{-2} \mu \mathrm{M}$.

\section{Acknowledgment}

The authors wish to thank Prof. Hiroshi Tomiyasu and Dr. Masayuki Harada, Research Laboratory for Nuclear Reactors, Tokyo Institute of Technology, for permitting to use the equipment necessary for the uranyl sorption experiments.

\section{References}

1. N. Kabay and H. Egawa, Sep. Sci. Technol, 29, 135 (1994).

2. T. Hirotsu, N. Takagi, and S. Katoh, Bull, Soc. Sea Water Sci. Jpn., 49, 202 (1995).

3. F. Eloy and R. Lenaers, Chem. Rev., 62, 155(1962).

4. B.-W. Zhang, K. Fischer, D. Bieniek and A. Kettrup, React. Polym., 20, 207 (1993).

5. H. Kubota and Y. Shigehisa, J. Appl. Polym. Sci, 56, 147 (1995).

6. W. Lin, Y. Lu, and H. Zeng, J. Appl. Polym. Sci., 47, 45(1993).

7. N. Kabay, A. Katakai, T. Sugo, and H. Egawa, $J$. Appl. Polym. Sci., 49, 599(1993).

8. A. Goto, K. Kusakabe, S. Morooka, and T. Kago, Sep. Sci. Technol., 28, 1273(1993).

9. N. Kabay, Sep. Sci. Technol., 29, 375 (1994).

10. H. Egawa, N. Kabay, T. Shuto, and A. Jyo, Ind. Eng. Chem. Res., 32, 540(1993).

11. K. Sekiguchi, K. Serizawa, S. Konishi, K. Saito, S. Furusaki, and T. Sugo, React. Polym., 23, 141 (1994).

12. N. Aoki, K. Tanaka, K. Furuhata, and M. Sakamoto, Sen'i Gakkaishi, 51, 586 (1995).

13. F. Schouteden, Makromol. Chem., 27, 246 (1958).

14. Y. Kobuke, H. Tanaka, and H. Ogoshi, Polym. J., 22, 179(1990).

15. K. Kusakabe, A. Goto, and S. Morooka, Sep. Sci. Technol., 29, 1567 (1994).

16. T. S. Lee and S.I. Hong, J. Appl. Polym. Sci., 57, 311 (1995).

17. N. Aoki, K. Fukushima, H. Kurakata, M. Sakamoto, and K. Furuhata, React. Funct. Polym., in press.

18. H. Egawa, N. Kabay, T. Nonaka, and T. Shuto, Bull. Soc. Sea Water Sci. Jpn., 45, 87 (1991). 
G. A. Pearse, Jr. and R.T. Pflaum, J. Am. Chem. Soc., 81, 6505(1959).

M. Nakayama, K. Uemura, T. Nonaka, and H. Egawa, J. Appl. Polym. Sci., 36, 1617 (1988)

T. Kato, T. Kago, K. Kusakabe, S. Morooka, and H. Egawa, J. Chem. Eng. Jpn., 23, (1990) 744.
22. H. Omichi, A. Katakai, T. Sugo, and J. Okamoto, Sep. Sci. Technol., 20, 163(1985).

23. H. Egawa, M. Nakayama, T. Nonaka, $H$. Yamamoto, and K. Uemura, J. Appl. Polym. Sci., 34, 1557 (1987). 